\title{
The Role of Biofertilization in Improving Apple Productivity-A Review
}

\author{
Walid Fediala Abd El-Gleel Mosa1,2*, Lidia Sas Paszt1', Mateusz Frąc ${ }^{1}$, Paweł Trzciński¹ \\ ${ }^{1}$ Research Institute of Horticulture, Konstytucji 3 Maja 1/3, 96-100 Skierniewice, Poland \\ ${ }^{2}$ Plant Production Department, Faculty of Agriculture (Saba Basha), Alexandria University, Alexandria, Egypt \\ Email: ${ }^{*}$ walidbreeder@yahoo.com
}

Received 15 December 2014; accepted 30 December 2014; published 13 January 2015

Copyright (C) 2015 by authors and Scientific Research Publishing Inc.

This work is licensed under the Creative Commons Attribution International License (CC BY).

http://creativecommons.org/licenses/by/4.0/

(c) (i) Open Access

\begin{abstract}
Biofertilization of crops with plant growth promoting microorganisms is currently considered as a healthy alternative to chemical fertilization. Biofertilizers are microbial preparations containing living cells of different microorganisms which have the ability to mobilize plant nutrients in soil from unusable to usable form. They are environmentally friendly, play a significant role in the crop production, help to build up the lost microflora and improve the soil health. Also, they increase crop yield by $20 \%-30 \%$, stimulate plant growth, are cost effective and provide optimal conditions for soil biological activity. They suppress pathogenic soil organisms, restore natural soil fertility and provide protection against drought and some soil borne diseases. Moreover, they degrade toxic organic chemicals, improve seed germination and aid in balancing soil pH in reducing soil erosion.
\end{abstract}

\section{Keywords}

Biofertilization, Apple Productivity, Arbuscular Mycorrhiza, Vermicomposting, Animal Manure

\section{Introduction}

Continuous use of chemical fertilization leads to deterioration of soil characteristics and fertility, and accumulation of heavy metals in plant tissues, affecting the fruit nutritional value and edibility [1].

Biological fertilization is based on the use of natural inputs including fertilizers, decaying remains of organic matter, excess crops, domestic sewage, animal manure and microorganisms such as fungi and bacteria [2]. Biofertilization is now a very important method for providing the plants with their nutritional requirements without having an undesirable impact on the environment [3]. Biofertilizers are known to improve fixation of nutrients

${ }^{*}$ Corresponding author. 
in the rhizosphere, produce growth stimulants for plants, improve soil stability and provide biological control. They also biodegrade substances, recycle nutrients, promote mycorrhiza symbiosis and develop bioremediation processes in soils contaminated with toxic, xenobiotic and recalcitrant substances [4]. Biofertilizers containing azotobacter produce many growth regulators such as IAA and GA2 which positively influence plant growth [5].

Apples are one of the most widely grown tree fruit. Apple trees originated in Central Asia and the first five countries in the apple production are China, the United States, India, Turkey and Poland respectively. Global average apple yields rose from $11 \mathrm{t} / \mathrm{ha}$ in 2002 to more than $15 \mathrm{t} / \mathrm{ha}$ in 2012. Apples rank third in global fruit production with about 76 million tonnes in 2012 (FAOSTAT 2014). Apple is a temperate crop adapted naturally to cold conditions and requires cold temperatures below $70^{\circ} \mathrm{C}$ for about 30 days to initiate flowering (this is called chilling). There are thousands of different varieties of apples including Fuji, Gala, Red Delicious, Golden Delicious, Pink Lady and Granny Smith. While most apples are eaten fresh, they have other uses including juice making and cooking. Apples are wonderful fruits because their components are essential for optimal growth, development and overall wellness. Moreover, they are low in calories, contain no saturated fats or cholesterol and are rich in dietary fibers, which help prevent absorption of dietary-LDL or bad cholesterol in the gut. The fibers also save the colon mucous membrane from exposure to toxic substances by binding to cancer-causing chemicals inside the colon. Apples are also rich in antioxidant phyto-nutrients flavonoids and polyphenolics and these compounds keep the body from deleterious effects of free radicals. Furthermore, apple fruits contain good quantities of vitamins and beta-carotene and carry a small amount of minerals like potassium, phosphorus and calcium.

The soil application of biological and mineral fertilizers and their complex on the parameters of growth and cropping of "Charavnitsa" apple variety budded on the semi-dwarfing 57 - 545 rootstock was studied by [6]. It was found that the application of biological fertilizers alone or in combination with the mineral fertilizers had positive influences on the leaf plate area, mean fruit weight and fruit chemical composition. They significantly lowered soil acidity to the optimum level for apple trees and considerably increased the contents of soil potassium, phosphorus and humus. On the opposite side, the authors noticed that application of mineral fertilizers had a negative effect on tree growth and yield. Moreover, they increased soil acidity and caused a slight increase of potassium, phosphorus and humus content.

The effects of various fertilizers depending on the number of treatments applied to maiden apple trees of the cultivars "Topaz and Ariwa" grafted on M.26 rootstock were studied by [7]. The plants were treated either once or twice with such products as granulated manure, Micosat, Humus UP, Humus Active + Aktywit PM, BF Amin, BF Quality, Tytanit ${ }^{\circledR}$ and Vinassa. The control plants were not fertilized at all, nor fertilized with NPK. The fertilizers were applied the first time to the soil and plants in the nursery in mid-May and the second time in early June. It was concluded that the single application of Tytanit ${ }^{\circledR}$ in the organic nursery seemed to be sufficient treatment for improving the quality of maiden apple trees. The biological activity of such preparations as Micosat, BF Amin, BF Quality and Vinassa used in the organic nursery of apple trees increased with the number of treatments performed. In terms of the quality of maiden trees, using these preparations twice was more effective than a single application. Cultivars of apple trees in the nursery responded differently to the same number of treatments with given biopreparations. In some of them, sufficiently good results were obtained with the single treatment, while to achieve a similar effect in others the same treatment must be performed twice. Regardless of the number of treatments, vermiculites (humic preparations) seem to be less effective in stimulating the growth of maiden apple trees than the extracts from marine plants (BF Quality), terrestrial plants (BF Amin) or Vinassa preparation. Mineral fertilization, the way which is commonly used in conventional nurseries, resulted in apple maidens whose quality was, if not poorer, at least comparable with those that were fertilized with organic products.

\section{Arbuscular Mycorrhiza (AM)}

Arbuscular mycorrhizal fungi (AMF) are obligate biotrophs, which can form mutualistic symbiosis with the roots of around $80 \%$ of plant species [8]. They represent $10 \%$ or more of the soil microbial biomass and establish a mutual symbiosis with the majority, approximately $80 \%$, of land plant species and agricultural crops [9]. It is well documented that AM symbiosis can increase plant growth and nutrient uptake, improve fruit quality and alleviate several abiotic stresses such as low temperature stress, drought and salt stress [10].

Under unsterilized low P field conditions, inoculation of greenhouse-produced apple seedlings by mycorrhi- 
zae before field planting can significantly increase the growth at least in the first season after planting as compared to both phosphorus-fertilized and unfertilized [11]. These results indicate the benefit of planting apple plants pre-colonized with a highly compatible VAM-fungus, even when the plants become colonized by the indigenous VAM-flora once they are in the field.

Apple trees show a strong dependency on mycorrhizae [12], and in orchards they form symbiosis with the naturally occurring vesicular-arbuscular mycorrhizal (VAM) flora [13]. Mycorrhiza benefit apple plants by improving growth and nutrition [14], involving mainly $\mathrm{P}$ and, in some cases, other immobile nutrients such as $\mathrm{Zn}$ and $\mathrm{Cu}$ [15]. There are numerous reports in the literature on the effects of inoculation with AMF on the assimilation and accumulation of phosphorus and other nutrients by the roots of apple trees [16]. There have been many studies on the use of mycorrhizal fungi to inoculate apple plants grown in in-vitro cultures, which can help in the acclimatization of these plants to field conditions [17].

\section{Composting}

Compost is a stable aerobically decomposed organic matter. It is a biologically active material mostly, organic origin that can vary in the texture. It is typically dark brown with an earthy appearance and smell [18]. Compost is the result of a managed decomposition process in which successions of aerobic micro-organisms break down and transform organic material into a range of increasingly complex organic substances, many of which are loosely referred to as humus. These substances are responsible for many of the important characteristics of high quality, healthy soils including their ability to hold plant available nutrients and moisture. Compost is ideally made from a mixture of organic materials that are blended to achieve an appropriate carbon to nitrogen ratio. Regardless of the method used, the composting process is managed to maintain temperature, oxygen and moisture levels within accepted ranges. Compost can be produced using a range of equipment from basic pile turning with front-end loaders to sophisticated in-vessel processing. However it is a process management rather than equipment that determines compost quality.

Composts increase soil biodiversity, which is essential to maintaining soil health [19]. The addition of compost to the soil improved fertility, water-holding capacity, bulk density and biological properties [20].

Adding organic composts to apple orchard soils has been shown to improve the blooming and growth of newly planted trees [21]. Also, the use of composts as part of an organic approach to apple production has been shown to be cost effective when compared with conventional practices [22].

\section{Vermicomposting}

Vermicomposting is a method of preparing enriched compost with the use of earthworms. It is one of the easiest methods to recycle agricultural wastes and to produce quality compost. Earthworms consume biomass and excrete it in digested form called worm casts. Worm casts are popularly called as black gold. The casts are rich in nutrients, growth promoting substances, beneficial soil micro flora and having properties of inhibiting pathogenic microbes. Vermicompost is stable and fin granular organic manure, which enriches soil quality by improving its physicochemical and biological properties. It is a highly useful in raising seedlings and for crop production. Vermicompost is becoming popular as a major component of organic farming system. The level of nutrients in compost depends upon the source of the raw material and the species of earthworm. A fine worm cast is rich in N, P and $\mathrm{K}$ besides other nutrients. Nutrients in vermicompost are in readily available form and are released within a month of application.

Vermicompost provides efficient conversion of organic wastes, crop and animal residues. It is a stable and enriched soil conditioner which helps in reducing population of pathogenic microbes and toxicity of heavy metals. Also, it is economic, environmentally safe nutrient supplement for organic food production, easy and low cost applied technology.

Vermicompost is rich in nutrients like potassium, nitrate, sodium, calcium, magnesium, chloride and has the potential for improving plant growth than pit compost and garden soil (control) [23].

A study on the use of vermicompost in apple orchards in Himachal Pradesh, India was conducted by [24]. The author used vermicompost once a year between $5-15 \mathrm{~kg}$ per plant. About $12-30 \mathrm{~cm}$ growth per year was observed in apple trees. The quantity and quality of the apple fruits have increased, both in terms of size and taste. Also, the storage value of fruit has been increased, the apple soil quality has improved and the apple farmers in India have practically given up the use of chemical fertilizers. 


\section{Humus}

Humic substances are recognized as a key component of the soil fertility properties, since they control the chemical and biological properties of the rhizosphere [25]. They are the subjects of studies in various areas of agriculture such as soil chemistry, fertility, plant physiology and environmental sciences, as the multiple roles played by these materials can greatly improve plant growth and nutrient uptake [26]. Many investigators reported that, application of humic substances led to a remarkable increment in soil organic matter which improve plant growth and increase crop production [27]. Humic acid is a product contains many elements which improve the soil fertility and increase the availability of nutrient elements by holding them on mineral surfaces and, consequently, affect plant growth and yield [28]. Humic materials significantly enhanced apple fruit weight, yield and soluble solids content [29]. Humic materials increased yield, fruit quality and grower income of apple [30]. Humic acid application (especially soil treatment with $20 \mathrm{ml} /$ tree, every week from July 1st to October 15th) markedly minimized the harmful effect of salinity and enhanced apple salt tolerance [31]. The optimal combination of chemical compound fertilizer (CF) (control, CF0; low, CF1; medium, CF1.5; high, CF2 rates) and humic acid to improve soil, leaf properties, yield and quality of apple in the Loess Plateau of China was investigated by [32]. The obtained results of this study suggested that the application of humic acid to chemical compound fertilizer enhanced the soil chemical properties, leaf quality, vegetative growth, fruit quality and yield of apple. The main response parameters reached their maximums at CF1.5 and CF2 rates without and with humic acid, respectively. Humic acid application to the soil may decrease chemical compound fertilizer application rate to reduce the production cost, but without compromising apple tree growth, fruit yield and quality. The application of humic acid and chemical compound fertilizer combination can be considered as a moderate and economical measure of fertilization for apple trees.

\section{Animal Manure}

Organic fertilizers, such as cattle manure, have long since been known to improve physical, chemical and biological properties of soils, particularly increasing the humus content and decreasing acidity [33]. Cattle manure had a favourable effect through decreasing acidity due to the significant proportion of $\mathrm{H}_{2} \mathrm{CO}_{3}$ reacting with the soil adsorption complex [34].

The effects of long-term amendment of organic manure and nitrogen fertilizer on nitrous oxide emission in a sandy loam soil were examined by [35]. It was found that the addition of organic manure in the tested sandy loam might be a good management option since it seldom caused a burst of $\mathrm{N}_{2} \mathrm{O}$ emission but sequestered atmospheric $\mathrm{C}$ and maintained efficiently applied $\mathrm{N}$ in soil.

Soil moisture distribution, nutrient content and apple productivity under organic farming technology by using organic manures (commercial organic manure and farm yard manure) were investigated by [36]. The obtained results revealed that moisture availability, $\mathrm{pH}$, organic carbon and nutrient status of the soil were significantly improved under organic manures. These parameters were also, at the maximum by the application of commercial organic manure at the rate of $20 \mathrm{~kg}$ and farm yard manure at the rate of $100 \mathrm{~kg}$ per every tree during both years of the experiment. Growth parameters, fruit characteristics, yield and fruits quality were at maximum levels under the application of the same rates during both the years of experiment.

\section{Tytanit $®$}

Tytanit ${ }^{\circledR}$ is a chemical element occurs within a number of mineral deposits, principally rutile and ilmenite, which are widely distributed in the earth's crust and lithosphere. It is found in almost all living things, rocks, water bodies and soils. It is the ninth-most abundant element in the earth's crust and the seventh-most abundant metal. Titanium involves in enhancing the chlorophyll content of leaves by promoting photosynthesis, this activation in photosynthesis is done by acting on the redox state of the acting protein with the enzyme fructose-1, 6-bisphosphatase and also, over other carbohydrate pathways [37]. Also, it limits the damage to plants caused by heavy metals [38]. It has been shown to have a beneficial effect on enhancing iron ion activity, pollen grain vigour, rate of nutrient uptake and improvement health condition of plants [39]. Titanium had a positive effect to improve the plant vigour of apple trees at a limited uptake of $\mathrm{Fe}, \mathrm{Mn}, \mathrm{Zn}$ and $\mathrm{Cu}$ [40]. Single application of Ty$\operatorname{tanit} \AA$ in the organic nursery seems to be a sufficient treatment for improving the quality of maiden apple trees [7]. 


\section{By-Products}

Molasses, the noncrystallizable residue remaining after sucrose purification, has some advantages: it is a relatively inexpensive raw material, readily available, does not require starch hydrolysis and is already used for ethanol production [41]. The molasses obtained after sugar beet processing contains about $60 \%$ sucrose and $40 \%$ of other components. The nonsucrose substances include inorganic salts, raffinose, kestose, organic acids and nitrogen containing compounds. Molasses is used in the production of baker's yeast, in fermentation technology for ethanol, citric, lactic and gluconic acids production, as well as glycerol, butanol and acetone production, as an ingredient of mixed feeds or in the production of amino acids. Baker's yeast (Saccharomyces cerevisiae) is the preferred fermenting microorganism for ethanol production because of its superior and well-documented industrial performances. Other yeasts, referred to as nonconventional yeasts, have also been studied for ethanol production. Among them are those that endure much lower $\mathrm{pH}$ than the Saccharomyces species, such as Zygosaccharomyces sp., as well as those that perform ethanolic fermentation at temperatures above $40^{\circ} \mathrm{C}$, such as hansenula polymorpha [42]. The influence of various bio-fertilizers on the growth and fruiting of "Ariwa" apple trees was examined by [43]. The obtained results cleared that the quality of the fruits was favorably affected by Vinassa.

\section{The Results Discussed in This Paper Allow Stating the Following Conclusions}

- Biological fertilization is economically efficient and sustainable alternative to standard NPK fertilization in apple production.

- All the discussed products reveal a positive influence on vegetative growth and yielding of apple trees.

- Due to successive effect of biological fertilization in apple growing, the most pronounced impact of biological products is observed after some years of their applications.

- Further field trails are needed to establish a proper dose and frequency of applications of biological products in apple production in order to obtain the most beneficial influence on yield and its quality.

\section{Acknowledgements}

The work has been supported by the grant from the EU Regional Development Fund through the Polish Innovation Economy Operational Program, contract No. UDA-POIG. 01.03.01-10-109/08.

\section{References}

[1] Shimbo, S., Zhang, Z.W., Watanabe, T., Nakatsuka, H., Matsuda-Inoguch, N., Higashikawa, K. and Ikeda, M. (2001) Cadmium and Lead Contents in Rice and Other Cereal Products in Japan in 1998-2000. Science of the Total Environment, 281, 165-175. http://dx.doi.org/10.1016/S0048-9697(01)00844-0

[2] Chirinos, J., Leal, A. and Montilla, J. (2006) Use Alternative Biological Inputs for Sustainable Agriculture in the South of Anzoategui State. Applied and Interdisciplinary Sciences, Biotechnology. Digital Magazine Ceniap Today, 11, 1-7.

[3] Abou El-Yazied, A.M. and Sellim, A.S.M. (2007) Effect of Reducing N, P Mineral Fertilization Levels Combined with Bio Fertilizer on Growth, Yield and Tuber Quality of Potato Plants. Journal of Agricultural Sciences, 32, 2701-2726.

[4] Rivera-Cruz, M., Trujillo, A., Córdova, G., Kohler, J., Caravaca, F. and Roldán, A. (2008) Poultry Manure and Banana Waste Are Effective Bio-Fertilizer Carriers for Promoting Plant Growth and Soil Sustainability in Banana Crops. Soil Biology and Biochemistry, 40, 3092-3095. http://dx.doi.org/10.1016/j.soilbio.2008.09.003

[5] Sharma, S.D. and Kumar, P. (2008) Relationship of Arbuscular Mycorrhizal Fungi and Azotobacter with Plant Growth, Fruit Yield, Soil and Leaf Nutrient Status of Mango Orchards in Northwestern Himalayan Region of India. Journal of Applied Horticulture, 10, 172-178.

[6] Tamara, V. R., Nadezhda, G. K. and Natalya, A. M. (2005) Influence of soil application of biological and mineral fertilizers on the growth, yield, and fruit biochemical components of 'charavnitsa' apple, and on some agrochemical soil characteristics. Acta Scientiarum Polonorum, Hortorum Cultus, 4, 59-67.

[7] Grzyb, Z.S., Piotrowski, W., Bielicki, P. and Sas Paszt, L. (2012) Quality of Apple Maidens as Influenced by the Frequency of Application of Different Fertilizers in the Organic Nursery Preliminary Results. Journal of Fruit and Ornamental Plant Research, 20, 41-49. http://dx.doi.org/10.2478/v10290-012-0014-8

[8] Giovannetti, M. (2008) Structure, Extent and Functional Significance of Belowground Arbuscular Mycorrhizal Networks. In: Varma, A., Ed., Mycorrhiza: State of the Art, Genetics and Molecular Biology, Eco-Function, Biotechnology, Eco-Physiology, Structure and Systematics, 3rd Edition, Springer-Verlag, Berlin and Heidelberg, 59-72. 
http://dx.doi.org/10.1007/978-3-540-78826-3 3

[9] Smith, S.E. and Read D.J. (2008) Mycorrhizal Symbiosis. 3rd Edition, Academic Press, San Diego.

[10] Miransari, M. (2010) Contribution of Arbuscular Mycorrhizal Symbiosis to Plant Growth under Different Types of Soil Stress. Plant Biology, 12, 563-569.

[11] Plenchette, C., Furlan, V. and Fortin, J.A. (1981) Growth Stimulation of Apple Trees in Unsterilized Soil under Field Conditions with VA Mycorrhiza Inoculation. Canadian Journal of Botany, 59, 2003-2008. http://dx.doi.org/10.1139/b81-262

[12] Koch, B.L., Covey, R.P. and Larsen H.J. (1982) Response of Apple Seedlings in Fumigated Soil to Phosphorous and Vesicular-Arbuscular Mycorrhiza. HortScience, 17, 232-233.

[13] Dalpé, Y., Granger, R.L. and Furlan, V. (1986) Abondance relative et diversité des Endogonacées dans un sol de verger du Québec. Canadian Journal of Botany, 64, 912-917. http://dx.doi.org/10.1139/b86-122

[14] Miller, D.D., Domoto, P.A. and Walker, C. (1985) Colonization and Efficacy of Different Endomycorrhizal Fungi with Apple Seedlings at Two Phosphorus Levels. New Phytologist, 100, 393-402. http://dx.doi.org/10.1111/j.1469-8137.1985.tb02788.x

[15] Gnekow, M.A. and Marschner, H. (1989) Role of VA-Mycorrhiza in Growth and Mineral Nutrition of Apple (Malus domestica) Rootstock Cuttings. Plant and Soil, 119, 285-293. http://dx.doi.org/10.1007/BF02370421

[16] Cavallazzi, J.R.P., Filho, O.K., Stürmer, S.L., Rygiewicz, P.T. and De Mendonça, M.M. (2007) Screening and Selecting Arbuscular Mycorrhizal Fungi for Inoculating Micropropagated Apple Rootstocks in Acid Soils. Plant Cell, Tissue and Organ Culture, 90, 117-129. http://dx.doi.org/10.1007/s11240-006-9163-6

[17] Meikle, T.W. and Amaranthus, M. (2008) The Influence of Fertilization Regime and Mycorrhizal Inoculum on out Planting Success: A Field Trial of Containerized Seedlings in Oregon. Native Plants Journal, 9, 107-116. http://dx.doi.org/10.2979/NPJ.2008.9.2.107

[18] Paulin, R. and O’Malley, P.J. (2008) Compost Production and Use in Horticulture. Bulletin/Western Australia, Department of Agriculture and Food, South Perth. http://archive.agric.wa.gov.au/objtwr/imported_assets/content/hort/compost_bulletin08.pdf

[19] Kennedy, A.C. (1999) Bacterial Diversity in Agroecosystems. Agriculture Ecosystems and Environment, 74, 65-76. http://dx.doi.org/10.1016/S0167-8809(99)00030-4

[20] Flavel, T.C. and Murphy D.V. (2006) Carbon and Nitrogen Mineralization Rates after Application of Organic Amendments to Soil. Journal of Environmental Quality, 35, 183-193. http://dx.doi.org/10.2134/jeq2005.0022

[21] Autio, W.R., Greene, D.W., Cooley, D.R. and Schupp, J.R. (1991) Improving the Growth of Newly Planted Apple Trees. HortScience, 26, 840-843.

[22] Reganold, J.P., Glover, J.D., Andrews, P.K. and Hinman, H.R. (2001) Sustainability of Three Apple Production Systems. Nature, 410, 926-930. http://dx.doi.org/10.1038/35073574

[23] Khan, A. and Ishaq, F. (2011) Chemical Nutrient Analysis of Different Composts (Vermicompost and Pitcompost) and Their Effect on the Growth of a Vegetative Crop Pisum sativum. Asian Journal of Plant Science and Research, 1, 116130. www.pelagiaresearchlibrary.com

[24] Vineet, S. (2012) Use of Vermicompost in Apple Orchards in Himachal Pradesh, India. Agricultural Science, 1, 17-44.

[25] Nardi, S., Tosoni, M., Pizzeghello, D., Provenzano, M.R., Cilenti, A., Sturaro, A., Rella, R. and Vianello A. (2005) Chemical Characteristics and Biological Activity of Organic Substances Extracted from Soils by Root Exudates. Soil Science Society of America Journal, 69, 2012-2019. http://dx.doi.org/10.2136/sssaj2004.0401

[26] Paksoy, M., Turkmen, O. and Dursun, A. (2010) Effects of Potassium and Humic Acid on Emergence, Growth and Nutrient Contents of Okra (Abelmoschus esculentus L.) Seedling under Saline Soil Conditions. African Journal of Biotechnology, 9, 5343-5346.

[27] Mahmoud, A.R. and Hafez, M.M. (2010) Increasing Productivity of Potato Plants (Solanum tuberosum L.) by Using Potassium Fertilizer and Humic Acid Application. International Journal of Academic Research, 2, 83-88.

[28] Akinci, S., Buyukkeskin, T., Eroglu, A. and Erdogan, B.E. (2009) The Effect of Humic Acid on Nutrient Composition in Broad Bean (Vicia faba L.) Roots. Notulae Scientia Biologicae, 1, 81-87.

[29] Li, N., Wang, X.X. and Lu, B.L. (1999) Study of the Effect of Apple Liquid Fertilizer on the Growth and Fruit Development of Apple. China Fruits, 4, 20-21.

[30] Fathi, M.A., Eissa, F.M. and Yahia, M.M. (2002) Improving Growth, Yield and Fruit Quality of "Desert Red" Peach and "Anna" Apple by Using Some Biostimulants. Minia Journal of Agricultural Research and Development, 22, 519534.

[31] Eissa, F.M., Fathi, M.A. and El Shall, S.A. (2007) The Role of Humic Acid and Rootstock in Enhancing Salt Tolerance 
of “Anna” Apple Seedlings. Journal of Agricultural Sciences, 32, 3667-3682.

[32] Zhang, L., Zhou, J., Zhao, Y.G., Zhai, Y., Wang, K., Alva, A.K. and Paramasivam, S. (2013) Optimal Combination of Chemical Compound Fertilizer and Humic Acid to Improve Soil and Leaf Properties, Yield and Quality of Apple (Malus domestica). Pakistan Journal of Botany, 45, 1315-1320.

[33] Ganzhara, N.F. (1998) Humus, Soil Properties and Yield. Eurasian Soil Science, 31, 738-745.

[34] Glisic, P.I., Milosevic, M.T., Glisic, S.I. and Milosevic, T.N. (2009) The Effect of Natural Zeolites and Organic Fertilizers on the Characteristics of Degraded Soils and Yield of Crops Grown in Western Serbia. Land Degradation and Development, 20, 33-40. http://dx.doi.org/10.1002/ldr.875

[35] Ding, W., Meng, L., Cai, Z. and Han, F. (2007) Effects of Long-Term Amendment of Organic Manure and Nitrogen Fertilizer on Nitrous Oxide Emission in a Sandy Loam Soil. Journal of Environmental Sciences, 19, 185-193. http://dx.doi.org/10.1016/S1001-0742(07)60030-8

[36] Verma, M.L., Rakesh, S., Charan, S. and Rathore, A.C. (2010) Influence of Organic Manuring on Apple Performance and Soil Properties in Temperate Zone of Himachal Pradesh. Indian Journal of Soil Conservation, 38, 212-216.

[37] Daood, H.G., Biacs, P., Fehér, M., Hajdu, F. and Pais, I. (1998) Effect of Titanium on the Activity of Lipoxygenase. Journal of Plant Nutrition, 11, 505-516. http://dx.doi.org/10.1080/01904168809363818

[38] Leskó, K., István Pais, S. and Simon-Sarkadi, L. (2002) Effect of Cadmium and Titanium-Ascorbate Stress on Biological Active Compounds in Wheat Seedlings. Journal of Plant Nutrition, 25, 2571-2581. http://dx.doi.org/10.1081/PLN-120014714

[39] Michalski, P. (2008) The Effect of Tytanit on the Yield Structure and the Fruit Size of Strawberry "Senga Sengana" and "Elsanta". Agricultura, 63, 109-118.

[40] Wójcik, P. (2002) Vigor and Nutrition of Apple Trees in Nursery as Influenced by Titanium Sprays. Journal of Plant Nutrition, 25, 1129-1138. http://dx.doi.org/10.1081/PLN-120003944

[41] Sánchez, O.J. and Cardona, C.A. (2008) Trends in the Biotechnological Production of Fuel Ethanol from Different Feedstocks. Bioresource Technology, 99, 5270-5295. http://dx.doi.org/10.1016/j.biortech.2007.11.013

[42] Satyanarayana, T. and Kunze, G. (2009) Yeast Biotechnology: Diversity and Applications. Springer, Berlin. http://dx.doi.org/10.1007/978-1-4020-8292-4

[43] Rozpara, E., Pąśko, M., Bielicki, P. and Sas Paszt, L. (2014) Influence of Various Bio-Fertilizers on the Growth and Fruiting of "Ariwa" Apple Trees Growing in an Organic Orchard. Journal of Research and Applications in Agricultural Engineering, 59, 65-68. 
Scientific Research Publishing (SCIRP) is one of the largest Open Access journal publishers. It is currently publishing more than 200 open access, online, peer-reviewed journals covering a wide range of academic disciplines. SCIRP serves the worldwide academic communities and contributes to the progress and application of science with its publication.

Other selected journals from SCIRP are listed as below. Submit your manuscript to us via either submit@scirp.org or Online Submission Portal.
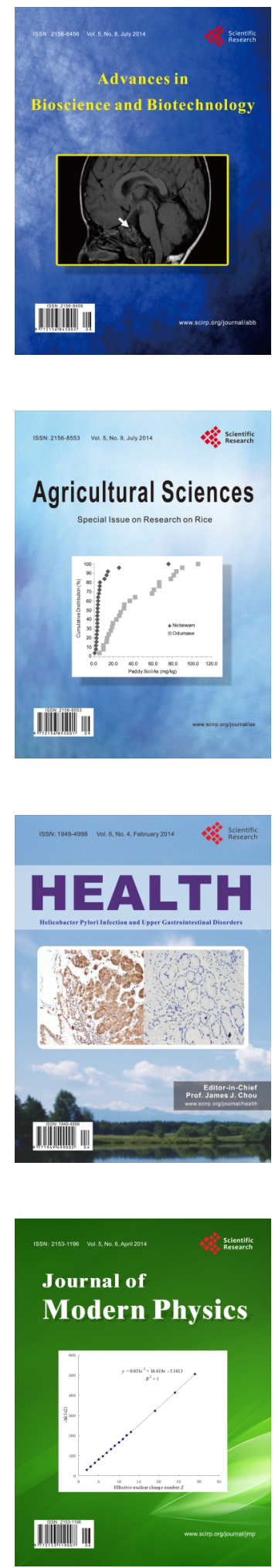
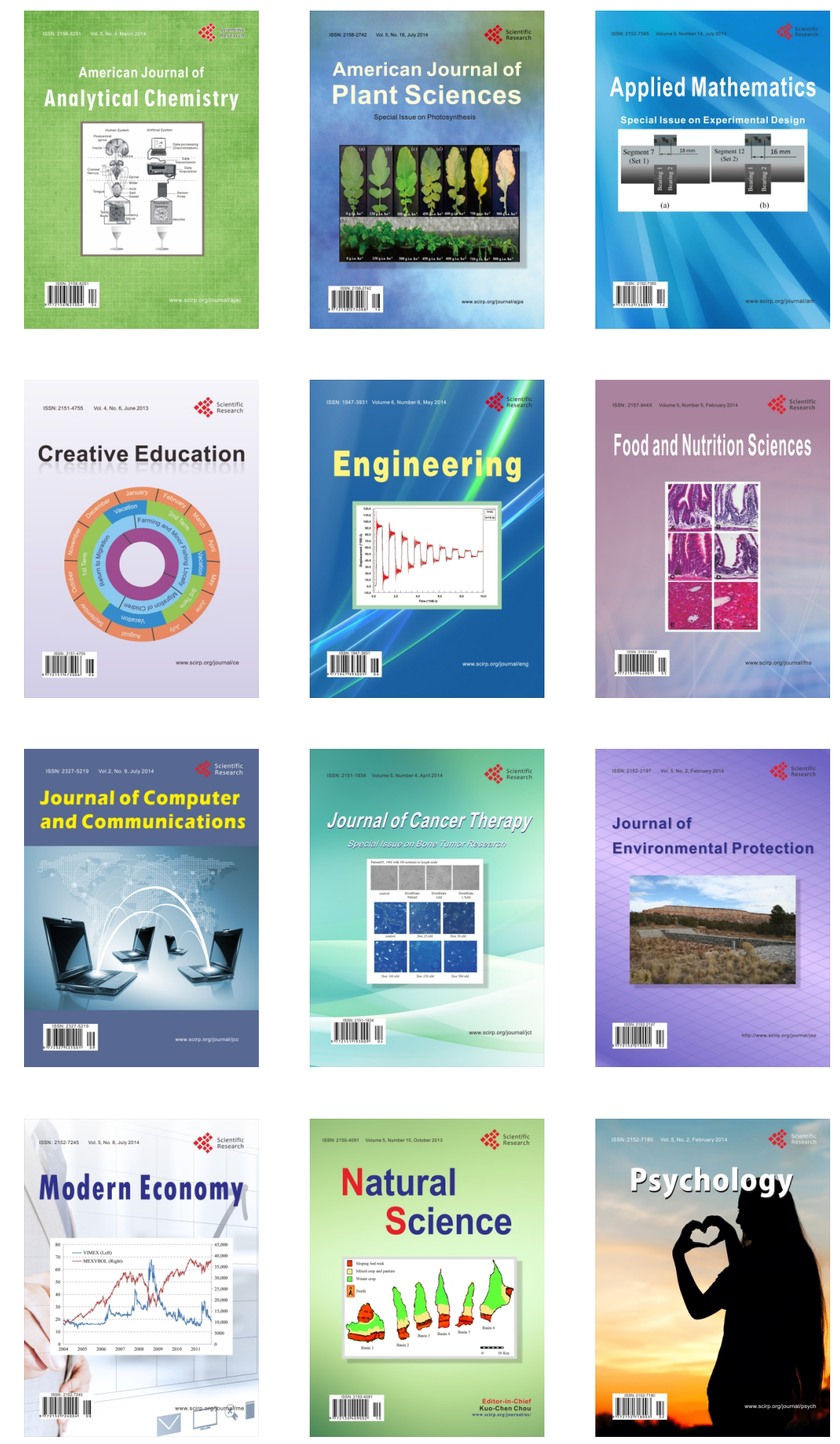